Journal of Social Sciences 6 (2): 240-243, 2010

ISSN 1549-3652

(C) 2010 Science Publications

\title{
Learning outcomes between Socioscientific Issues-Based Learning and Conventional Learning Activities
}

\author{
${ }^{1}$ Piyaluk Wongsri and ${ }^{2}$ Prasart Nuangchalerm \\ ${ }^{1}$ Koratpittayakom School, Amphoe Muang, Nakhonratchasima 30310 Thailand \\ ${ }^{2}$ Department of Curriculum and Instruction, Faculty of Education, \\ Mahasarakham University, Mahasarakham 44000 Thailand
}

\begin{abstract}
Problem statement: Socioscientific issues-based learning activity is essential for scientific reasoning skills and it could be used for analyzing problems be applied to each situation for more successful and suitable. The purposes of this research aimed to compare learning achievement, analytical thinking and moral reasoning of seventh grade students who were organized between socioscientific issues-based learning and conventional learning activities. Approach: The samples used in research were 72 of seventh grade students in the first semester of academic year 2009 at Koratpittayakom School, Muang District, Nakhonratchasima Province. The sample groups were divided into two groups by assignment for socioscientific issues-based classroom and conventional classroom. The research instruments used in this research were twelve plans for organization learning activities using socioscientific issues-based instruction and conventional instruction, an achievement test with discriminating powers) $\mathrm{B}$ (its ranging was $0.27-0.68$ and reliability was 0.85 , difficulty) $\mathrm{P}$ (ranging of analytical thinking test was $0.53-0.77$ with discriminating powers ranging, $0.78-0.30$ its reliability was 0.78 and discriminating powers) B (ranging 0.31-0.58, moral reasoning test had reliability 0.85 . Quantitative data were analyzed by using mean, standard deviation, percentage, Hotelling's $\mathrm{T}^{2}$ and Univariate $\mathrm{t}$ test. Results: The results can be revealed that students who learned by socioscientific issues-based instruction had learning achievement, analytical thinking and moral reasoning than those conventional instruction at 0.05 level of significantly statistics. Conclusion: In conclusion, students who learned by socioscientific-issues-based learn showed learning achievement, analytical thinking and moral reasoning than those conventional instructions. Therefore, teachers supported to implement socioscientific issues-based instruction in science teaching for the future.
\end{abstract}

Key words: Socioscientific issues-based instruction, learning achievement, analytical thinking, moral reasoning, science teaching, science education, learning model

\section{INTRODUCTION}

Today, science teaching is informed decision making, ability to analyze, synthesize and evaluate information into classroom. It also deals with moral reasoning and ethical issues try to understand the connections among socioscientific issues. The joint construction of scientific knowledge that is at once personally relevant and socially shared therefore relies on exposure to and careful analysis of, cases involving considerations of data, evidence and argumentation that may be in conflict with one's existing conceptions regarding various socioscientific moral and ethical issues. Socioscientific issues may be equated with the consideration of ethical issues and construction of moral judgments about scientific topics via social interaction and discourse (Zeidler et al., 2005). The instructional activities should inform the nature of science and scientific inquiry, as well as moral and ethical dimensions of science education Students are expected to develop an understanding their conceptual science if they are informed decisions regarding the scientifically based personal and societal issues (Sadler et al., 2004; 2006; Sadler and Zeidler, 2004; Nuangchalerm, 2010).

Global warming and climate change are widely talked. The effects can influence to all of area in our society, it need to be instructed in school science and also let students know and understand about nature of science. This situation, teaching science is not only referring to the lesson, but also social interaction in terms of controversial between science and society are stimulated and need to incorporate into school (Nuangchalerm, 2010). When we have a good science

Corresponding Author: Piyaluk Wongsri, Koratpittayakom School, Amphoe Muang, Nakhonratchasima 30310 Thailand 
teaching it can help our society to prepare good society and gain community to aware present and future (Tal and Kedmi, 2006). For preparing future students, the way to learn and modify socioscientific issues need to incorporated in school science. Students should be learned toward understanding of concepts related to holistic views in terms of ecosystem dynamics and decision making based on moral and ethic dimensions (Sadler, 2004; Nuangchalerm, 2009).

In addition, we need to solve social and environmental problems with many methods, especially science education which it is process of science teaching for people have scientific, technological, environmental and social awareness (Kennedy et al., 2009). At this point, our students should be known and understandable how to survive in our society with happiness. The way of science education is an appropriate way to promote scientific literacy students because they are growing to work and live in the society (Kollmuss and Agyeman, 2002). Also, the pedagogical aspects in science need to have inquiring mind in science and make them to meet both scientific facts and creativity. The learning perspectives also have all been considered as an important of science education goals (Bell and Lederman, 2003). School science is to enable students to observe their natural environment and to develop skills required to understand and explain both themselves and their environment (Marx et al., 2004).

The approaches challenges to instructional strategies based on reality of science teaching and moral and ethics aspects. This study aims to (i) investigate effective teaching criterion through socioscientific issues-based teaching at $80 / 80$, (ii) find out effectiveness index of socioscientific issues-based teaching, (iii) compare analytical thinking between before and after students had learned by socioscientific issues-based learning activities and (iv) study learning satisfaction of fifth grade students after they had learned through socioscientific issues-based instruction. The results of this study can help students meet nature of science and stimulate them to have habit of mind in science.

Objective: To compare learning achievement, analytical thinking and moral reasoning of seventh grade organized between socioscientific issues-based instruction and conventional learning

Hypothesis: Learning achievement, analytical thinking and moral reasoning of seventh grade organized between socioscientific issues-based instruction and conventional learning are difference.

\section{MATERIALS AND METHODS}

\section{Populations and sample:}

- The populations of this research comprised of seven classrooms, 280 of 7 th grade students attending in the first semester, academic year 2009 of Koratpittayakom school

- The samples of the research were 72 of seventh grade students attending in the first semester, academic year 2009 of Koratpittayakom School, Nakhonratchasima province by cluster random sampling. Thirty eight students were from 1 classroom was socioscientific issues-based instruction and another classroom with thirty four students was conventional instruction

Research tools: There were four kinds of the research tools used for this research as follows:

- There were 2 kinds of lesson plans, including twelve lesson plans of socioscientific issues-based instruction and conventional instruction. The researchers spent $24 \mathrm{~h}$ to finish these plans

- Achievement test with fifty items of four multiple choices, its discrimination power was between 0.27 and 0.68 and reliability was 0.85

- Twenty items of four multiple choices test on analytical thinking, its difficulty index was between 0.35 and 0.77 , its discrimination power was between 0.30 and 0.78 and the test reliability was 0.78

- Twenty items of five rating scale on moral reasoning questionnaire, its discrimination power was between 0.31 and 0.58 and the test reliability was 0.85

Data collection and analysis: This research conducted pre-test with two groups of experiment by achievement test, analytical thinking and moral reasoning questionnaire. Then, two instructional practices were implemented and followed by Post-test. Data were analyzed were mean, percentage and standard deviation. The research hypothesis was approved by Hotelling's $\mathrm{T}^{2}$.

\section{RESULTS}

Researchers analyzed the correlation of learning achievement, analytical thinking and moral reasoning between socioscientific issues-based and conventional instructions (Table 1).

Three variables-learning achievement, analytical thinking and moral reasoning were correlated in statistical significance of differences. Then researchers employed three variables test by Hotelling's $\mathrm{T}^{2}$ (Table 2). 
Table 1: Correlation of learning achievement, analytical thinking and moral reasoning

\begin{tabular}{llll}
\hline Correlation & $\begin{array}{l}\text { Learning } \\
\text { achievement }\end{array}$ & $\begin{array}{l}\text { Analytical } \\
\text { thinking }\end{array}$ & $\begin{array}{l}\text { Moral } \\
\text { reasoning }\end{array}$ \\
\hline Learning achievement & - & $0.506^{* *}$ & $0.324^{* *}$ \\
Analytical thinking & $0.506^{* *}$ & - & $0.271^{*}$ \\
Moral reasoning & $0.324^{* *}$ & $0.271^{*}$ & - \\
\hline *: Statistical significance of differences at $0.05 ; * *:$ & Statistical \\
significance of differences at 0.01 & &
\end{tabular}

Table 2: Test of mean differences among learning achievement, analytical thinking and moral reasoning

\begin{tabular}{llllll}
\hline Statistical test & Value & Hypothesis & Error \\
DF & DF & F & P \\
\hline Pillai's trace & 0.461 & 3 & 68 & $19.383^{*}$ & 0 \\
wilks'lambda & 0.539 & 3 & 68 & $19.383^{*}$ & 0 \\
Hotelling's trace & 0.855 & 3 & 68 & $19.383^{*}$ & 0 \\
Roy's largest root & 0.855 & 3 & 68 & $19.383^{*}$ & 0 \\
\hline *: Statistical significance of differences at 0.05 & & &
\end{tabular}

Table 3: Comparisons of learning achievement, analytical thinking and moral reasoning by Univariate t test

\begin{tabular}{llllll}
\hline Variables & SS & DF & MS & F & P \\
\hline Learning achievement & 256.003 & 1 & 256.003 & $9.608^{*}$ & 0.003 \\
Contrast error & 1865.108 & 70 & 26.644 & & \\
Analytical thinking & 218.267 & 1 & 218.267 & $43.208^{*}$ & 0.000 \\
Contrast error & 353.608 & 70 & 5.052 & & \\
Moral reasoning & 1688.285 & 1 & 1688.285 & $16.567^{*}$ & 0.000 \\
Contrast error & 7133.659 & 70 & 101.909 & & \\
\hline
\end{tabular}

*: Statistical significance of differences at 0.05

Learning achievement, analytical thinking and moral reasoning of seventh grade students learned by socioscientific issues-based instruction and conventional instruction were different at 0.05 level of statistical significance. Then, researchers employed Univariate $t$ test for testing power of variables between two methods of instruction (Table 3).

Students who learned by Socioscientific issuesbased instruction had learning achievement, analytical thinking and moral reasoning than those conventional instruction at 0.05 level of statistical significance.

\section{DISCUSSION}

Socioscientific issues-based instruction can develop students' skills in discussion ethical issues (Sadler and Zeidler, 2005), represent important social issues and problems which are conceptually related to science in societal dimension (Sadler et al., 2006). Students also can develop their scientific knowledge and inquiry practices for the negotiation of science and society concerns. Therefore, inquiry and negotiation of SSI require the integration of science concepts and processes with social constructs and practices. These may influence individuals' scientific reasoning.

In promoting scientific literacy and nature of science, science classroom should be incorporated socioscientific issues-based instruction. This reflected their own dominantly rationalistic reasoning about the issue, as well as their sense of their role and limited knowledge about socioscientific and technological criteria (Nuangchalerm, 2009). While scientific practice include conceptual understanding and skills, commonly promoted in science. Exploring scientific controversies is one pedagogical approach that allows students to critically evaluate and debate competing scientific claims. Sadler and Zeidler (2005) suggest that differences in content knowledge are related to variations in the quality of informal reasoning. In this study, the students that possessed more advanced understandings of related science concepts had greater quality of reasoning.

\section{CONCLUSION}

The socioscientific issues-based instruction can develop students' achievement, analytical thinking and moral reasoning. Teachers should have instructional pedagogy relevant to controversial issues as students are facing the changing world. Also, teachers should support students to have learning proficiency by implementing socioscientific issues-based instruction in science teaching for the future.

\section{REFERENCES}

Bell, R.L. and N.G. Lederman, 2003. Understanding of the nature of science and decision making on science and technology based issues. Sci. Educ., 87: 352-377.

http://ir.library.oregonstate.edu/jspui/bitstream/19 57/13534/1/BellRandyL1999.pdf

Kennedy, E.H., T.M. Beckley, B.L. McFarlane and S. Nadeau, 2009. Why we don't "walk the talk": Understanding the environmental values/behavior gap in Canada. H. Ecol. Rev., 16: 151-160. http://www.humanecologyreview.org/pastissues/her 162/kennedyetal.pdf

Kollmuss, J. and J. Agyeman, 2002. Mind the gap: Why do people act environmentally and what are the barriers to pro-environmental behavior? Environ. Educ. $\quad$ Res., $\quad$ 8: 239-260. https://www.d.umn.edu/ kgilbert/educ5165731/pwreadings/Mind\%20Gap.pdf

Marx, R.W., P.C. Blumenfeld, J.S. Krajcik, B. Fishman and E. Soloway et al., 2004. Inquiry-based science in the middle grades: Assessment of learning in urban systemic reform. J. Res. Sci. Teac., 41: 1063-1080. http://www.its-abouttime.com/htmls/pbis/ letuspaper.pdf 
Nuangchalerm, P., 2009. Development of socioscientific issues-based teaching for preserves science teachers. J. Soc. Sci., 5: 239-243. http://eric.ed.gov/ERICDocs/data/ericdocs2sq1/cont ent_storage_01/0000019b/80/45/15/f0.pdf

Nuangchalerm, P., 2010. Engaging students to perceive nature of science through socioscientific issuesbased instruction. Eur. J. Soc. Sci., 13: 34-37. http://www.eurojournals.com/ejss_13_1_04.pdf

Sadler, T.D. and D.L. Zeidler, 2004. The morality of socioscientific issues construal and resolution of genetic engineering dilemmas. Sci. Educ., 88: 4-27. http://www.coe.ufl.edu/Faculty/tsadler/construal.pdf

Sadler, T.D. and D.L. Zeidler, 2005. The significance of content knowledge for informal reasoning regarding socioscientific issues: Applying genetics knowledge to genetic engineering issues. Sci. Educ., 89: 71-93. http://www3.interscience.wiley.com/journal/10960 4723/abstract

Sadler, T.D., 2004. Informal reasoning regarding socioscientific issues: A critical review of research. J. Res. Sci. Teac., 41: 513-536. http://www.coe.ufl.edu/Faculty/tsadler/IRSSI.pdf
Sadler, T.D., F.W. Chambers and D.L. Zeidler, 2004. Student conceptualizations of the nature of science in response to a socioscientific issue. Int. J. Sci. Educ., 26: 387-409. http://www.informaworld.com/index/713765549.pdf Sadler, T.D., A. Amirshokoohi, M. Kazempour and K.M. Allspaw, 2006. Socioscience and ethics in science classrooms: Teacher perspectives and strategies. J. Res. Sci. Teach., 43: 353-376. http://www.coe.ufl.edu/Faculty/tsadler/SSEthics.pdf

Tal, T. and Y. Kedmi, 2006. Teaching socioscientific issues: Classroom culture and students' performances. Cult. St. Sci. Educ., 1: 615-644. http://stwww.weizmann.ac.il/g-chem/docs/TAL.pdf

Zeidler, D.L., T.D. Sadler, M.L. Simmons and E.V. Howes, 2005. Beyond STS: A research-based framework for socioscientific issues education. Sci. Educ., 89: 357-377.

http://www.coe.ufl.edu/Faculty/tsadler/BeyondSTS .pdf 